\title{
Megan's Law: Crime and Democracy in Late Modern America
}

Jonathan Simon

To an unprecedented degree American society at the turn of the twentieth century is governed through crime. Nearly three percent of adults are in the custody of the correctional system. Crime and fear of crime enter into a large part of the fundamental decisions in life: where to live, how to raise your family, where to locate your business, where and when to shop, and so on. The crime victim has become the veritable outline of a new form of political subjectivity. This essay explores the complex entanglements of democracy and governing through crime. The effort to build democratic governance after the American Revolution was carried out in part through the problem of crime and punishment. Today, however, the enormous expansion of governing through crime endangers the effort to reinvent democracy for the twenty-first century.

Crime and punishment have come to play a central role in the ongoing reconstruction of liberal government and its rationalities in the United States and some other postmodern/postindustrial societies (Simon 1997, 1999a). ${ }^{1}$ Two of the most visible aspects of this occur in the field of electoral politics and in the correctional population. The centrality of crime to

Jonathan Simon is professor of Law, University of Miami. This article is a report of an ongoing investigation to which many people and institutions have contributed. The first version of this article was prepared as a paper for the Law and Society Summer Institute 1996 and revised in response to critical discussion by the other participants in that Institute, including Rob Rosen, Kim Scheppele, Tom Tyler, Mark Galanter, and Jennifer Culbert. Special thanks to Jo Carrillo and Rob Rosen for organizing the institute. Subsequent versions of the article were presented to faculty workshops at NYU and Yale. Special thanks to Bruce Ackerman, Joseph Kennedy, and Reva Siegel for comments on those drafts.

1. A case can be made that this is a wider pattern of the English-speaking postindustrial nations including Australia, Canada, Great Britain, and New Zealand, as well as the United States. Although the U.S. rates are dramatically higher than others in this Anglophone group, the other nations are high in comparison to other regional peers (Currie 1998). 
electoral politics and the formal actions of state and federal politicians has long since become conventional wisdom (Wattenburg 1995; Dionne, 1991). When the history of the U.S. party system at the end of the twentieth century is completed, crime may nudge out the Cold War, and earn a place along with the Great Depression, as the issues around which fundamental regime shifts took place.

After two decades or more of a "severity revolution" (Kennedy forthcoming) U.S. prisons and their community adjuncts contain a population unprecedented in the history of the United States or any of our peer societies (Currie 1998; Caplow and Simon 1999). With nearly 3\% of the adult population in some form of penal custody (Maguire and Pastore 1998, 464), ${ }^{2}$ crime policy has by itself reversed what most people take to be a shrinking of the role of government in society since the late 1970s (Beckett and Western 1999; forthcoming).

Less obvious is the spread of crime as an organizing problem to the actual sites of governing, (e.g., universities, day care centers, factories and shopping centers). The colossal mass of that penal population serves to reorder the lives of those outside the prison walls in complex ways. Of course it is intended to do that. In institutional setting after institutional setting one can spell out the ways that the very real sanctions applicable to conduct described as criminal produce powerful incentives for strategic action by all players. The importance of crime nudges out other kinds of opportunities that a different hierarchy of public problems might produce (e.g., a government obsessed with governing by educating would produce all kinds of incentives to define various people as efficient or deficient in education, capable or incapable, and so on). The economic metaphor of incentive is essential for capturing how basic the appeal of crime is, but as a metaphor it misses important features of the phenomenon. Crime is a genre, in the dramaturgical sense. It comes with certain kinds of roles; vulnerable victims, willing offenders, vigilant prosecutors, and harsh but fair judges (and all the deviant variations those set up). When we govern through crime we pass out these scripts to hundreds if not thousands of real people with little in the way of an audition and no accountability for the consequences. ${ }^{3}$

In introducing the slogan "governing through crime" I have sought to bring together a growing body of literature within political science, critical criminology, and sociology, pointing out the unprecedented growth of the penal state and its adjuncts and seeking to explain the causes and

2. This status is not evenly distributed in the population. Those in custody at any given time make up nearly $5 \%$ of the male adult population, and almost $10 \%$ of the African American adult population (Maguire and Pastore 1998).

3. Crime and punishment are a vast archive of political subjectivities from the formation of a "bad boy" (Deveare-Smith 1993, 100) or "bad ass" (Katz 1988) subjectivity necessary for survival in certain neighborhoods (Anderson 1998), to learning how to be a "confidence man" as a defense lawyer (Blumberg 1967). 
consequences (Radzinowicz 1991; Zimring and Hawkins 1995; Scheingold 1991; Christie 1993; Gordon 1994; Kaminer 1995; Tonry 1995; Donziger 1996; Miller 1996; Garland 1996; Beckett 1997; Parenti 1998; Stern 1998; Schlosser 1998; Young 1999; Wacquant 1999; Caplow and Simon 1999) with work on the history of the governmental rationalities through which political authority is realized as a capacity to know and regulate the population (Foucault 1991; Dean 1991; Barry, Osborne, and Rose 1996; Garland 1997; Rose 1999; Simon 2000). I take the return of criminal law to a pivotal role in government as coincident with a profound transformation in the nature of liberal governance, not only in the United States but, in some forms, across most of the postindustrial world.

In all these societies, the basic intellectual "software" (Balkin 1998) of governance has been undergoing change over the past three decades (Rose and Miller 1992; Rose 1999; Procaci 1998). Forms of knowledge associated with "the social" (e.g., sociology, social work, and the close-up study of the lives of the poor) have all experienced downward mobility (Baudrillard 1983; Rose 1996; Simon 1999b). Likewise, technologies of power associated with what some have called the "social activist state" (Garth and Sterling 1998), like social insurance (Ewald 1986, 1991), fiscal stimulus policy, and regulation, have in varying degrees declined. ${ }^{4} \mathrm{~A}$ whole family of rationalities of governing through defining social problems, shifting risks and responsibilities from the individual to the collective level, and empowering governmental organizations to intervene seems to be passing into history.

The political figures most famously associated with the turn away from welfare and regulation, Margaret Thatcher and Ronald Reagan, were figures of the political right. The emerging knowledge and power strategies of governance, however, are best seen as a kind of "advanced liberalism" (Rose and Miller 1992; Rose 1999), where liberalism is understood as a broad family of strategies for governing people through rather than over their freedom (Rose 1999). It is consistent with this view that successors like Tony Blair in Great Britain and Bill Clinton in the United States are considered well to the left of Thatcher and Reagan, but have also embraced many of the same forms of expertise and many of the same technologies of power.

In the United States crime has turned out to be a major platform for reconstructing liberal governance. While not inevitable, this association has roots in American culture, the vicissitudes of crime rates, and memories in the generational pattern of American society. Moreover, it has consequences for the way "advanced liberalism" is being played out in the United States. The penal population is an example of those most thoroughly

4. Alternative expertise associated with systems management, risk assessment, and new therapies of self-improvement (Rose and Miller 1992; Cruikshank 1994), among others, have gained prestige and become more central to government. New strategies for governing emphasize disaggregating masses (of consumers, students, workers, etc.), intensifying the responsibility of individuals, and promoting market mechanisms for individual, firm, or family choice. 
governed through crime. The past 20 years has seen the correctional subject tied ever more tightly to his or her crime, so that the likelihood of going to prison depends mostly on the crime and the criminal record, and the regime in prison is more defined by the moral status of crime (i.e., punitive). Upon release the prisoners find themselves in a wider correctional population difficult to exit from (Simon 1993). Recent laws aim at making the mark of criminal conviction more consequential for educational opportunities, access to employment, and welfare.

If the correctional population was the central story of governing through crime it would form a disturbing but subordinate element in the construction of an advanced liberal governance in the United States. In fact, this is only the core of a constellation of relationships, including those governed as victims (Madriz 1997), as potential victims, as potential offenders, as people who know and might influence potential victims or potential offenders. ${ }^{5}$ Governing through crime in this sense means making crime the defining feature of the subject's relationship to power.

In addition to bringing the full range of truth and power effects of crime into the discussion, a governance perspective requires us to look beyond the model of simple behavioral conformity to consider the ways technologies of power both act on and produce knowledge of the subject. To exercise power is inevitably and sometimes inexorably to alter the governability of the subjects on whom power is being exercised. ${ }^{6}$ In a larger project, I am currently seeking to map these changes across a whole set of institutional domains including schools, employment relations, debtor/creditor relations and the family. Here I want to focus on a crucial slice of that landscape, the practices of political freedom we know generally as democracy.

Part 1 discusses crime control as an integral part of three strands of what might be called democratic penal traditions. Part 2 examines three different but related accounts of how the embedding of governing through crime into the new regime of liberal governance taking shape in the United

5. This should be distinguished from the narrower concern with governing criminal behavior that has been the traditional function of the criminal justice system. Indeed, once we take this perspective seriously we can see that the vast majority of people governed through crime control are not recalcitrant and oppositional, but in fact are highly motivated to seek out and comply with behavioral controls designed to make them safer. Moreover, these measures can operate to reinforce hierarchies at all sorts of levels.

6. The influence of Foucault on the study of the reciprocal links between penality and governance should not be overstated. Of great value here is the tradition of British Marxist and cultural studies of law and the social order. The role of crime and the criminal justice system in constructing power relations in eighteenth-century England has been the subject of extensive research by E. P. Thompson (1975), Douglas Hay (1975), Peter Linebaugh (1992), and others. A very different and potentially more comparable case is the work of Stuart Hall (Hall et. al. 1979), Paul Gilroy (1987) and others on the intersection of race, class, and crime in England during the long British economic slump of the late 1970s and 1980s. These works form the basis for a comparative study of governing through crime that would yield useful insights. 
States might disable a democratic society. Part 3 briefly considers a recent example of penal legislation, the wave of sex-offender notification laws adopted in the mid-1990s under the name "Megan's Law," to suggest how these democratic traditions and dangers intertwine in forms of contemporary governance.

\section{DEMOCRATIC PENAL STRATEGIES}

Crime and punishment were central concerns of democratizing forces in the United States at the end of the eighteenth century. ${ }^{7}$ Even a cursory reading of the U.S. Constitution shows the revolutionary generation's vivid concern with crime control as governance. Cruel and unusual punishments (Eighth Amendment); the right to jury, counsel, and to confront your accusers (Sixth Amendment); freedom from multiple prosecutions and the right not to testify against oneself (Fifth Amendment); the right to be free from unreasonable searches and seizures (Fourth Amendment) all loom large there. For that generation the struggle with monarchy was as much embedded in institutions of criminal justice as it was in the scenes of battle or the radical printing presses also invoked in that document. The theory of American democracy called for the sovereign to give up forms of preventive repression of the population so typical of the monarchical style of rule, but in equal measure it demanded a criminal law able to respond forcefully to the predatory invasion of private rights. Criminal laws in this respect have always served as the definitive grammar of American democratic governance. Reform of the criminal law, preferably into a highly transparent criminal code, and the creation of punishments that would efficiently discourage crime have been constitutive projects for the republic almost from the beginning. Substantive criminal law jurisprudence reflects this relationship to freedom in its traditional requirements that punishment be limited to those subjects sufficiently free of internal delusion or external coercions by some system of regulation other than those of the law itself (Kaplan, Weisberg, and Binder 2000, 687-747).

The ringing condemnation of monarchical procedures set out by the great Enlightenment political theorists left us a tradition of civil liberties that remains integral to liberal politics and government (Dubber 1998, 114). But the other side of this critique was a positive project of managing crime in a democratic way that protected the people from crime and provided even the guilty with treatment appropriate to sovereign self-governing

7. In other settings the emergence of the penitentiary had a more problematic relationship to democratization. For example in Latin America the penitentiary was associated with slavery and with modernizing dictatorships as well as with democrats (see Salvatore and Aguirre 1996). 
subjects. In what follows I want to briefly canvass some of the main strands of this positive democratic project of penality.

\section{A. Safer Correctives: Democracy and Deterrence}

But we have nothing to fear from the demoralizing reasoning of some, if others are left free to demonstrate their errors. And especially when the law stands ready to punish the first criminal act produced by the false reasoning. These are safer correctives then the conscience of a judge.

-Thomas Jefferson, Letter to Elijah Boardman

Among free men, the deterrents ordinarily to be applied to prevent crime are education and punishment for violations of the law, not abridgment of the rights of free speech and assembly.

-Louis Brandeis, Whitney v. California

A student of American constitutional law will recognize these sentiments (if not the words themselves) as central elements in the tradition of freedom of expression protected by the First Amendment to the U.S. Constitution. For monarchy, crime was the most obvious and dangerous fruit of unregulated speech. Seditious speech above all could destroy the bonds of loyalty and deference that kept colonial society ordered at all levels (state, plantation, family) (Wiebe 1985, 11). As the Supreme Court recognized in its famous New York Times v. Sullivan decision, 376 U.S. 254 (1964), the sovereign's renunciation of the authority to punish seditious libel was the core meaning of the First Amendment (Kalven 1965, 57-58).

The above quotes remind us how important an effective governmental response to crime was to the logic of liberalizing preventive controls on provocative behavior. Notice that for each, the governmental tools for responding to the danger of seditious speech is the combination of education and punishment. ${ }^{8}$ The central problem for deterrence as a democratic project early on was designing a distribution and publication of punishments just strong enough to outweigh the temptation for crime without producing the surplus pain and violence associated with monarchical punishments (Foucault 1977; Dubber 1998). It was to this end that new codes were rapidly drawn up in the years preceding and following the revolutions, a pattern that has periodically recurred since. ${ }^{9}$ Deterrence is both penal and political theory. It is here that penal strategy and liberal governmental

8. Interestingly, Brandeis defines both education and punishment for crime as part of deterrence. Deterrence requires both communication of the sanctions for violating a norm and the production of punishment.

9. Foucault $(1977,75)$ argues that these changes were already taking place under monarchical institutions. 
rationality most perfectly correlate. It is here that the penal machinery seems to operate directly on the calculative rationality of the democratic body politic. Deterrence has been the original and most enduring way of governing people through their freedom (i.e., through their capacity to make choices) (Rose 1999).

Perhaps for this reason, deterrence has been so frequently reinvented and rediscovered as a penal rationale. Since the 1960 s, libertarian and conservative policy thought has reemphasized the deterrence of the criminal law as the social control appropriate to a society of individual liberty and private property. ${ }^{10}$ In a rather striking and self-conscious parallel to the democratic critique of monarchical justice, the neo-liberal/neo-conservative discourse of deterrence condemned liberal government in the 1960 s and 1970 s for undermining the clarity of deterrent signals with talk of rehabilitation and treatment, and as a result, unleashing a wave of violent crime (Wilson 1983).

The case for deterrence and democracy has also been emphasized recently by outsider jurisprudence that looks to the criminal law to provide a counterbalance to violent forms of domination. One of the most significant examples of this is in the area of domestic violence and particularly violence against women. Feminists have waged a successful struggle in recent years in getting courts, police departments, and state legislatures to recognize domestic violence as a serious crime and to provide commensurate sanctions and enforcement policies (Berk and Loseke 1981). Much of this struggle has implicitly or explicitly accepted the deterrent force of the criminal law as an effective strategy for resisting the continuation of violent male domination within the household. This effort has required feminist legal scholars to engage in a thorough going critique of criminal-law and criminal-procedure constructs, and to identify and replace concepts that embody stereotypes of women which militate against the application of criminal law to violent male dominators (Coombs 1987; Mahoney 1991).

\section{B. Democracy and Discipline}

Social history in the 1970s, beginning with the path-breaking work of David J. Rothman, recalled to that time of social upheaval, the importance of the penitentiary and asylum-projects of social control - to the revolutionary generation that had won the war of independence and set out to a life of unprecedented democratic self-government for its preferred class of citizen (white males). The attraction of the prison as a new technology applicable to crime control at the end of the eighteenth century was due in

10. This is by now a formidable literature. Some of the most important landmarks are Becker 1968; Posner 1985; J. Q. Wilson 1983. 
part to the popularity of deterrence as a democratic theory of crime control (Ignatieff 1978). Deterrence called for a technology of readily divisible sanctions. The prison was such a technology through the seizure of time in the prison.

If deterrence explains the popularity of the prison as governmental technology in revolutionary America, it does not exhaust the possibilities of the prison. Deterrence was soon joined by another program of democratic penality, one drawing on the several centuries of experimentation in the fields of disciplinary training and rooted in the prison itself as transformative technology of power (Rothman 1971; Foucault 1977; Dumm 1987). Prison, in this tradition, was a machinery of reform, the penitentiary, that could transform those too unsettled by the Revolution and its aftermath to fully take up its invitation to self-government (Rothman 1971).

In the twentieth century this tradition reached its peak with formal establishment of rehabilitation as the dominant official ideology of state punishment in the United States and other democratic nations. Taking over in the reduction of penal severity from where the deterrence theorists had left it, rehabilitation promised to reduce punishment to the subtle humiliations of the medical situation in favor of effective methods for addressing criminal deviance at its roots in individual psychology and community disorganization (Rothman 1980; Simon 1993).

The prison as a technology of discipline, and later treatment, represented a fundamentally different way of imagining a democratic response to crime, a shift in the technologies through which power was exercised, and the fundamental terms in which it was rationalized. Deterrence focused on crime and punishment as a semiotic system designed to create the conditions for rational agents to behave cooperatively in a free society. In contrast, the penitentiary as a technology was targeted on specific individuals already identified as dangerously deviant through conviction for a serious crime. Deterrence operated like a communicative system "broadcasting" its message of norm compliance across society as a whole, while disciplinary normalization was rooted in particular locations and depended on its own concentrations of people to operate. For deterrence the punishment need only be reliably disagreeable, and as cheap as possible. For the penitentiary project, the design and method of the prison became of incalculable importance, thus unleashing one of the most heated policy debates of the early republic (Rothman 1971; Foucault 1977; Dumm 1987). ${ }^{11}$

Like deterrence, the rehabilitative project has failed many times without disappearing. Most recently, since the 1970s, rehabilitation has been

11. One model, that of Philadelphia, emphasized moral redemption through total isolation in a setting of individual labor and meditation. The second model, that of New York's Auburn prison, emphasized isolation only at night, with days filled with silent labor in common projects. See generally Dumm 1987. 
seen as a paradigmatic example of the failures of liberal governance. Despite vigorous efforts in progressive states like California during the 1960 s, correctionalists never managed to achieve much in the way of measurable success. More politically damaging, the level and viciousness of crime itself rose measurably during the 1960 s, the very period when rehabilitation enjoyed its closest association with the prestige of liberal government. Today disciplinary rehabilitation remains politically suspect, but it is not difficult to imagine its reinvention because its emphasis on technologies of individual transformation remains part of the political subjectivities produced by liberalism.

\section{We Feel Your Pain: Crime and Responsive Democracy}

In societies as different as Mexico, Trinidad, South Africa, and the United States, expansive electoral democracy has brought crime, fear of crime, and rituals of punishment to the center of electoral politics. Economic and social liberalization almost everywhere seem to yield real increases in crime as new opportunities and temptations are opened up by the ending of formal security states and the maintenance of monstrous levels of inequality. Politicians in liberalizing societies also have incentives to make crime a central focus for campaigning. Promises of sweeping economic reforms could yield immediate problems on the markets. Promising to strike hard against crime is likely to offend no important interests. Criminal laws and prosecutions are exemplary acts of popular will. Whether the subject is alcohol, prostitution, drugs, or pollution, campaigns to criminalize behavior perceived as antisocial, even if not assaultive, have often inspired democratic publics. ${ }^{12}$ Governing through crime in this sense is attractive to people because it permits popular fears and experiences to be valorized in the strongest and most public terms (Simon and Spaulding 1999).

We can see a contemporary version of this in the effort of prosecutors in states like Alabama, Mississippi, and Florida to bring prosecutions for violent crimes and murders committed by die-hard defenders of segregation against civil rights workers and ordinary African American citizens during the early 1960s. In most of the original cases charges resulted in acquittals or were never brought at all, as juries, prosecutors, and police seemed to collude in sheltering concededly fringe elements of the white community. Contemporary prosecution efforts have come at a time when these states in many other ways have continued to resist the civil rights revolution, preserving de facto segregated private "academies" and electing conservative

12. Of course, populist vengeance can become antidemocratic very quickly indeed if it is not locked into strong procedural restraints. In that sense we might well see the era of liberal due process jurisprudence in the United States as a necessary condition for crime and punishment to become a self-sustaining democratic engine. 
Republican legislatures opposed to affirmative action, public schools, and welfare benefits. Against such a background, new prosecutions for these old crimes represent valued gestures of recognition. Just as the violence of the early 1960s, and even more so the lynchings common in those states before the 1920 s, represented a clear signal that notwithstanding the formal adoption of the Thirteenth and Fourteenth Amendments, members of the former slave race were not going to be treated as equal citizens, today's prosecutions are a mark of equal citizenship.

\section{Tough on Crime As a Democratic Project}

In this section I suggest that governing through crime has an old and deep relationship to democratic governance itself. A rejection of monarchical penality is implicit in our tradition of civil liberties, but several strands of democratic penality also look to the power to punish to help fulfill the promise of self-government. In the course of two centuries during which the real scope of democratic life in the United States has expanded enormously (through, for example, the enfranchisement of women [1917] and African Americans [1950-80]), the meaning of government's commitment to security has expanded as well. Expanding democratization was associated with the declining importance of crime as a defining purpose of government. Indeed, for most of the twentieth century the primary icon of both crime and punishment at the national level was the reactionary image of the American Deep South, framed in acts of official barbarism and injustice and savage racially targeted criminality. The aspirations of progressive government lay elsewhere, in economic management, in education, in military preparedness. Criminal law and punishment were only a small part of this overall effort.

The striking return of crime, criminal law, and punishment to the center of the American political imaginary from 1980 on throws us back onto these strands of democratic penality that have never altogether disappeared but have been minor themes of government for a long time. The historical deposit of power in the scripts and metaphors of crime control has several consequences. It makes crime an enormously attractive site for government at a time when the dominant twentieth-century forms of government are being strongly contested. Just as the individual voter may find in harsh penalties aimed at malevolent violent offenders a sense of renewed solidarity with fellow citizens whose values and objectives have otherwise been problematized by globalization, multiculturalism, and other late-twentieth-century forms of postmodernization (Tyler et al. 1997, 247-48), politicians find in punishment a safe grammar for governing (Caplow and Simon 1999, 78-93). The "tough on crime" posture has served American politicians for almost as long since Nixon's election as the law-and-order 
candidate in 1968 (an election that would have been a landslide without George Wallace's appeal on many of the same themes) as the "New Deal" did between 1936 and 1968. Its enduring appeal reveals that it provides much more than an issue-specific response to voter concerns about crime. Instead "tough on crime" enables political actors to express commitment to the security of the people while avoiding debate on the difficult questions of how to manage the major forms of modern public security (pensions, insurance, public education). It also makes it possible to criticize more elaborate measures of government social policy (whether funding for the arts or fighting poverty) as undervaluing and even undercutting the strength of government's primary commitment to physical security.

Against this background we should properly hesitate before drawing the most distopian conclusions from the enormous expansion of the government's formal penal effort, or even from the expansion of different dimensions of crime (fear, victims, etc.) as a model for governing in different settings. Even as we appreciate the enduring entanglements between democracy and punishment left by the revolutions of the eighteenth century, we should be wary of taking on their focus on crime control as a tool of monarchical abuse as our primary metaphor for the ways this entanglement may endanger democracy. The real danger is not a return to premodern forms of political authority but the creation of postmodern social formations that are ungovernable democratically.

\section{GOVERNING THROUGH CRIME AS A THREAT TO DEMOCRATIC PRACTICE}

The philosopher and historian Friedrich Nietzsche was actually writing about the history of punishment when he made one of his most famous and enduring points about the relationship of the past to the present generally.

The origin of the emergence of a thing and its ultimate usefulness, its practical application and incorporation into a system of ends, are toto coelo separate; that anything in existence, having somehow come about, is continually interpreted anew, requisitioned anew, transformed and redirected to a new purpose by a power superior to it; that everything that occurs in the organic world consists of overpowering, dominating, and in their turn, overpowering and dominating consist of reinterpretation, adjustment, in the process of which their former 'meaning' [Sinn] and 'purpose' must necessarily be obscured or completely obliterated.... So people think punishment has evolved for the purpose of punishing. But every purpose and use is just a sign that the will to power has achieved mastery over something less powerful, and has impressed upon it its own idea [Sinn] of a use function. (1994, 55; emphasis in the original) 
The fact that crime control practices have long been central to the democratization project cannot assure that these same technologies and rationalities of power are a viable way to sustain democratic public life in the United States and similarly situated countries. Several recent accounts suggest quite different ways that our growing national commitment to punishment, and the cultural shifts around it, endanger the democratic character of the society. In this section I want to revisit these accounts (which are by no means exclusive) with a focus on the broader constellation of ways of knowing and ways of acting upon the world I call "governing through crime."

\section{A. Racism and Penality}

Few things are clearer in the history of the United States than the powerful links between racism and antidemocratic forces. This is especially true of prejudice against African Americans. The constitutional framework, developed to protect the enslavement of Africans at the dawn of our republic, required systematic limitations on the democratic character of the polity created including limitations on speech, franchise, and the right to travel (Foner 1988). Even after the Civil War and Reconstruction, anti-African racism has been a critical force unifying oligarchic elites and dividing the popular classes in American society (Woodward 1966).

In the mid-1990s nearly one in nine young African American males was in prison at least some of the year, and one in three was in prison, on parole or on probation (Miller 1996). However, in big cities with large zones of concentrated poverty, the penal custody rate is closer to half the population of young African American men (Donziger 1996, 102). In the course of a lifetime, nearly one-third of African American men will serve time in jail or prison (Bonczar and Beck 1997, 1). Nearly one in seven African American men have lost the right to vote as a result of a felony conviction (Felner and Mauer 1998). These simple demographic facts speak volumes about the role of criminal justice in undermining the expansion of democratic practice achieved in the third quartile of the twentieth century through the civil rights movement and its victories in education, equal employment opportunity, housing, and suffrage. Just as in Reconstruction, African American citizenship rights in the most punitive states may turn out to have had a historical longevity of only a generation or two. Criminal justice policy at the end of the twentieth century seems to be playing the role for the United States as a whole that segregation did in the "redemption" of the American South for white supremacy at the end of the nineteenth century.

Recent books by Miller (1996); Tonry (1995); Donziger (1996); Hagan and Peterson (1995); and Cole (1999) argue forcefully that U.S. crime 
control policies since 1980, from police stops to executions, with respect to their consequences for African American and Hispanic communities, reflect governmental attitudes ranging from willful and intentional discrimination to reckless disregard of a well-known risk (but see Kennedy 1997). Few scholarly observers believe that simple bias in the selection and treatment of criminal suspects fully explains the extreme racial skewing evident in incarceration and other forms of punishment. Whatever we ultimately make of the mountain of penal legislation produced by state legislatures and the U.S. Congress over the past quarter century, it was not analogous to the "Black Act" enacted by the eighteenth-century English gentry elite representing a mere fraction of the population (Thompson 1975). Voters have continuously ratified the expanding investment in law enforcement resources against crime. Even most African American elected representatives have supported harsh anti-crime laws until very recently.

While the motives of legislators are rarely simple racial animus, the results have been catastrophic for African Americans and other minorities overrepresented in the economic underclasses of American society (Tonry 1995). The resulting policing and prosecutorial strategies have affected African American communities in a variety of ways. During a period when the economic opportunities open to inner-city residents were at their worst since the Great Depression of the 1930s, the young men providing the major labor force for the illegal drug trade have hardly been the least functional members of the community. Their physical removal may or may not have affected the profits of the drug cartels, but they almost certainly made these communities less rather than more governable by removing young men who are fathers and sometimes breadwinners and exposing them to the hardening effects of incarceration (Meares 1998).

Jerome Miller $(1996,13)$ argues that crime-control policies have also aggravated racist sentiments in the majority population. The war on drugs and its policing have created a flood of minor convictions that in an earlier era would never have resulted in official action. Many of these arrests are for trivial acts and amount to what John Irwin (1985) called "rabble management." But the nearly endless spectacle of young African American men being led away by police and prison guards feeds the perception that violent crime is spiraling out of control and that African Americans are uniquely responsible for it as a community. Miller points out that the creation of a stereotype of African American crime has also helped facilitate the return of eugenically inclined thought in American political discourse $(1996,233)$.

The critique of contemporary crime-control policies as a racial strategy is compelling. Even if it does not explain the motives for either politicians or the public to govern through crime, the intersection of America's history of racial domination and its contemporary tendency to govern through crime contain grave threats to democratic order in the United States. 
Governing through crime, as simply racism by other means, seems most plausible at the level of electoral politics where crime/race ads have been hot-wire mobilizing issues for white voters since at least the 1950s. This approach to governance is also palpable in the appearance of the penal population itself, which is often a strikingly African American. Thus, it is not impossible to imagine contemporary prisons as the new plantations, or the new segregation. If the prison is the new "ghetto" (Wacquant forthcoming), a space that concentrates subjects by race and invests those racial subjects with social meanings and economic capacities, it functions as no previous racial regime has. For the first time in even the usually sordid racial history of the United States, a substantial racially defined population is being given economic significance primarily as a market for social waste management (profiting the largely white small towns seeking prison construction as employment development).

But if the new prison system has features of the ghetto and earlier forms of race making in the United States, racism is less descriptive of the features of punishment as an institution. Penal management is highly legalistic (Feeley and Rubin 1997). ${ }^{13}$ Penal staffs over the past generation have experienced real diversification due to affirmative action policies. Towns that have courted prisons may be white and rural, but because of state efforts to promote minority hiring they may find themselves drawing many more people of color, including families of penal staff and families of inmates. Furthermore, important African American opinion leaders view the war on crime and drugs as a critical feature of improving life for ordinary African Americans. ${ }^{14}$

Framing crime as a kind of modality of government offers an alternative account of the race effects and their consequence for democracy. Since the nineteenth-century American democracy has been anchored to mechanisms of collective opportunity and risk sharing, including public schools, social insurance, government loans, and pension systems. The politics of aggregation in America has always been laden with racial concerns. Indeed, one can look at the original New Deal, the great leap forward for the politics of aggregation in the United States, as a complex political compromise built on the exclusion of African Americans. This traditional and racialized anxiety about risk sharing across ethnic and class lines has taken on a new urgency in part because U.S. society has experienced a widespread rollback in the institutions of collective risk sharing. Beginning in the mid-1970s the political fortunes of unions, regulatory agencies, and most social welfare

13. Florida's Secretary of Corrections, himself an African American, was harshly critical of the "chain gang" innovation (Lichtenstein 1996).

14. For some time, Randall Kennedy has offered a powerful critique of law enforcement as underprotective of African Americans against crime (1997). A position that he acknowledges entails a heavy portion of African American defendants, since so much crime is intraracial. 
systems have all plummeted. A growing climate of mistrust has grown around even relatively beloved institutions like Social Security. Less beloved systems, like Aid to Families with Dependent Children, have been dismantled.

Rather than trying to bring criminal-justice policy and race politics into direct relationship, it may be more helpful to see their connection within the context of this restructuring of governance. The civil rights movement in the 1950s and 1960s destroyed that political consensus behind which the American version of social democracy was forged, but an emerging post-civil rights consensus is making crime the new logic of exclusion (Kennedy forthcoming). The "deviant other," whose presence endangers collective security, has been officially changed from all African American and other minorities, to an "underclass" largely defined by the criminal justice system. Crime normalizes what remained problematic when framed in explicitly racial terms. White flight to avoid school desegregation was an acknowledged social problem. Twenty years later, recoded as the divide between "high crime areas" and others, a whole set of tactics that remain ones of racial exclusion are being normalized (Davis 1990, 1998). For example, efforts to keep largely minority group city residents out of suburban shopping centers, parks, and residential communities have become commonplace.

Analogies in modern penal history might suggest room for hope. Looking at Edwardian Britain, David Garland (1985) showed how the extension of penal interventions beyond the prison into the community, and beyond crime into deviance, were part of a much larger process of bringing the working classes into governmental oversight and management. This, in turn, was a kind of quid pro quo for the extension of suffrage to the working class; in effect, the disciplinary control of criminal deviants was part and parcel of qualifying the working class for the privileges of self-government. A move from excluding African Americans on the basis of race to excluding many of them on the basis of crime might seem like forward progress toward full citizenship, so long as realistic opportunities enable the vast majority to evade the cycle of crime and punishment.

Today, however, criminalization does not function as a correlate to enhanced citizenship for two reasons. First, as other bases of exclusion have become less sustainable through the expansion of civil rights law, crime is doing a lot of the work of risk segregation today. Criminal conviction may be so disabling and stigmatizing today that few may be able to "requalify" as full citizens. Second, a hardening of criminal penalties has occurred simultaneously with a shrinking of the outlets for legitimate employment available to the inner-city poor (Sampson and Wilson 1995; W. J. Wilson 1996). ${ }^{15}$

15. It is a very significant problem that most of our theorizing and much of our empirical work on the links between the penal state and the inner-city poor date from the 1980s and 
To be marked as criminal is increasingly coming to function as a general forfeiture of legal rights without any apparent proportionality to the degree of responsibility, harm, or program for social control.

Seen from the governance perspective, this hybrid of race and crime poses a serious threat to democracy in its tendency to intensify the disaggregation of those collective opportunity and risk structures of modern government that American democracy has always relied on to resolve group conflicts within civil society. City limits and public school district lines have been allowed to become barriers more legally significant than those between states when it comes to carving up who shares fortune and danger with whom. ${ }^{16}$ Crime is used to justify isolating cities from private-sector investment even as public investment in crime control goes up. The high cost of managing the least manageable populations forces cities to raise taxes to levels that drive out those residents and businesses with the option to move, which in turn raises the tax bill for all remaining. In short, the racial effects of governing through crime may greatly shorten the time before the present governmental structure becomes unworkable.

\section{B. The Penal-Industrial Complex}

The rapid expansion of the penal system has led to the growth of a formidable power block of interest groups with a stake in continued escalation. Some have spoken of a parallel between the older military-industrial complex (Schiraldi 1994; Beckett 1997; Irwin and Austin 1997; Schlosser 1998). Since the end of the cold war in 1989, the overall public and private investment in crime responses now approaches investment in military defense after growing more rapidly for some time (Donziger 1996, 85). Like the military-industrial complex, this alliance crosses classes, enabling a broad coalition of interest to form behind the banner of increasingly severe punishment.

Punishment as a form of governmental power shares many features with the military that undermine democratic accountability. Both are capable of producing strong pressures against civil liberties, including the First Amendment's protections for speech and the Fifth Amendment's

early 1990s, before the economic boom of the late 1990s sent unemployment rates down to 1960 s levels, even for minorities. It remains to be seen exactly how the boom is producing economic opportunity for the "underclass." Ironically, it may be just as the boom begins to create pathways out for many young workers in the inner city that the social and economic consequences of governing through crime may become most destructive. The stigma of criminal conviction, given business fears of crime and liability, combined with hypermasculine and violent culture of prisons (Silberman 1995), make prisonization one of the worst imaginable labor policies (Beckett and Western 1999). From this perspective state laws extending the scope of prison sentences ought to be considered inflationary.

16. Milliken v. Bradley, 418 U.S. 717 (1974) (holding that federal courts lack the power to impose interdistrict remedies for school segregation). 
protections of property, as well as traditional criminal-procedure rights like the Fourth Amendment's right to be free of unreasonable searches and seizures. Both punishment and military defense draw on and reproduce powerful images of deviance as the source of collective and individual threat. These can lead to cycles of fear and demonization that are not easily cabined in traditional interest-group politics. Finally, both are highly expansive in that they open up possibilities for intervention along a much broader front of activities than their core functions. Virtually any activity can be seen in relationship to a powerful enough imperative like military defense or social defense against crime. The Cold War famously led to investments in highways, universities, and the Internet, all in the name of military competition with the Soviet Union. Crime spending has thus far been invested most heavily in prisons and the supplies needed to operate them, but crime control more generally can provide an agenda for school reform, urban renewal, architecture, and tax policy among other things.

As in the Cold War, important political-interest groups have formed a prison lobby for more severe punishment. In California, for example, the penal officers' union has emerged as one of the two or three largest contributors to legislative and other statewide campaigns (hugely expensive given the number of media markets in the state) (Donziger 1996, 96-97; Schrag 1998). In alliance with victim groups, other law enforcement lobbies, and key politicians, they have been able to halt internal efforts at slowing incarceration and enact major new expansions (like California's 3-strikes law).

While the comparison between the Cold War and governing through crime is imperfect, the two share some useful features. Both operated as master narratives for government at various levels of the state and in private organizations. Both provided ready motives for political actors, but also certain technologies of power and knowledge easily transferred to other ends. Thus far, however, the Cold War comes off as more helpful to democratic governing (with the possible exception of the nuclear threat that has, in any case, outlived it). The Cold War generated a broad front of governmental investments to enhance the capacities of the population in a whole host of ways functional to democracy (education, steady employment), but the resulting transformations in culture hardly fit a pattern of militarization. The universities expanded in the 1950s under a Cold War imperative, but by the 1960s when the concrete was dry and the classrooms were full, it was not ROTC and nationalist chauvinism that dominated campus life. The $\mathrm{Na}$ tional Defense Highway Act (1950) funded the interstate system that in turn transformed American culture in the second half of the twentieth century, but not along recognizably military lines. Once again Nietzsche's warning about origins and functions is appropriate.

Perhaps governing through crime will also produce effects well beyond the specific emotions and meanings that sustain it today. There is, however, 
less reason to be optimistic that the social payoff from the war on crime will be anything like the Cold War. In the war on crime, investment has overwhelmingly been in assets with little potential to accomplish any other goal than crime suppression. ${ }^{17}$ In contrast, the cultural spread of a punitive mentality as an integral feature of governance may be the real contribution of the prison boom. In short, the Cold War built a lot of new hardware for the society while producing relatively little militaristic "software."18 The war on crime is producing little usable hardware, but it's producing lots of punitive software. In this sense the Cold War analogy is only somewhat helpful in characterizing the punitive turn of governance. It is ultimately the things that governing through crime does not have in common with Cold War government that seem most significant.

\section{Victims, Vengeance, and Civic Culture}

Crime in this perspective is a potent stimulant to political community, but what kind of political community? It invests individuals with political subjectivity as victims, offenders, prosecutors, and judges. What does it mean for democracies if stakeholders in all kinds of communities begin to view themselves primarily as victims or potential victims? What happens when the most common aspirations for collective welfare are directed primarily to punishing and preventing crime or crime-like conduct? Recent works of political theory (Putnam 1993; Brown 1995) and cultural studies (Kaminer 1995) have begun to shed light on the logic of political relationships forged around crime. While not yet fully directed toward crime as a fulcrum of governance (but see Dumm 1994), this political theorizing suggests that the political solidarities forged through crime may turn out to be very fragile structures for building the effective democratic consensus necessary for taking the hard decisions and renegotiating the social contract of the liberal state as it experiences a reconfiguration of its rationalities of governing.

\section{Vicious Circles of Declining Civic Participation}

In an important study of the social conditions under which democratic governance seems to thrive, Robert Purnam and his colleagues (1993) raised some troubling implications for the growth of governing through crime. Putnam and his associates closely studied the experience of regional governments in Italy from the time they were constitutionally created in the early

17. One should say, deliberate goal, since our prisons are obviously quite capable of producing a range of pathologies ranging from violent racism to AIDS victims.

18. Jack Balkin (1998) uses software as a term for cultural programs that complete interpretive grids for subjects in societies. 
1970 s through the late 1980 s. They sought to measure the success of government both in its own terms, and in the view of relevant publics. They found a strongly consistent pattern over the entire period. After assessing various theoretical frameworks to explain the pattern of democratic success, Putnam and his colleagues found that the most important determinant in predicting the governmental effectiveness of a region was the character of its civic culture.

One type of civic culture, associated with a more successful governance, was characterized by cross-cutting horizontal bonds among people in popular associations ranging from sports clubs and bird-watching groups to technical societies. In such regions, democratic governance worked well because these horizontal bonds helped produce coherent objectives around which terms of agreement could be settled by bargaining-oriented institutions. Once objectives were determined, the chances for cooperation in implementation at all levels were also much higher. A second type of civic culture, associated with failed governance, was dominated by vertical ties of patronage linking otherwise inwardly focused individuals and families. In such regions, governance foundered on an absence of trust and the expectation of competent performance. In the absence of horizontal bonds, consensus takes the shape of deals cut among an elite, and implementation is hampered by the usual need in such settings to provide immediate incentives for cooperation.

It was in regions characterized by the second civic culture that Putnam found a tendency for political demands to coalescence around coercive enforcement of repressive norms-that is, strikingly close to what I have called "governing through crime."

Lacking the confident self-discipline of the civic regions, people in less civic regions are forced to rely on what Italians call "the forces of order," that is, the police. . . Citizens in the less civic regions have no other resort to solve the fundamental Hobbesian dilemma of public order, for they lack horizontal bonds of collective reciprocity that work more efficiently in the civic regions. In the absence of solidarity and self-discipline, hierarchy and force provide the only alternative to anarchy. (Putnam 1993, 112)

Unfortunately crime control fails in such an environment for many of the same reasons other governmental efforts founder in the absence of civic culture.

In the less civic regions even a heavy-handed government-the agent for law enforcement-is itself enfeebled by the uncivic social context. The very character of the community that leads citizens to demand stronger government makes it less likely that any government can be 
strong, at least if it remains democratic. (Putnam 1993, 113; emphasis added)

British criminologists Bill Jordan and Jon Arnold (1995) have suggested that the United States is already an advanced case of just such a vicious circle, and warn that British political culture may be on the same track. Jordan and Arnold see the development of ever-more-severe penal sanctions, like California's 3-strikes law, and the rhetoric of the Republican Party on crime as marks of a virulent populism. The emergence of crime as a central focus of political advantage-seeking both corrodes what remains of civic feeling among the populace and dominates other (presumably) healthier sources of democratic participation. Jordan and Arnold describe the direction in American political culture: "From inclusive to exclusive social interactions, with groups defining themselves in terms of opposition towards the values and goals of others, and recognising no wider (or common) interest, except in punitive enforcement" $(1995,172)$. Jordan and Arnold see the social effects of conservative social policies in the United Kingdom and the United States as largely to blame. These policies, designed to reward individual enterprise, have had the collateral effect of breaking up the incentive structures for horizontal civic culture. The result at the margins has been to drive more people into resistance strategies of illegality and raise the costs of all forms of governing $(1995,177)$.

The mobilization of political participation through crime and criminal justice polarizes society further by leading groups to define their relationships with others in extreme terms of moral outrage that make resolution through negotiation less likely. Consider, for example, the different ways of lowering the social cost of drunk driving (Gusfield 1981). A city might use zoning power and negotiation to compel pubs and taverns to locate in areas accessible to public transportation, or choose to subsidize extensive cab service or car pooling. An alternative strategy is to define drunk drivers as moral monsters and then expend significant efforts to catch, prosecute, and punish them. This approach leaves in place structural features that will guarantee a steady flow of drunk driving (i.e., the geographic distribution of taverns and the absence of effective public transportation). It also increases the cost for all kinds of other institutions that now must reassess their relationship to an individual in terms of that kind of status transformation. These measures also contribute to a distorted sense of how threatened people are by deviant others who engage in concededly reckless and irresponsible behavior (whether driving under the influence, smoking crack, or having unprotected sex). They also introduce tremendous sources of strain into the lives of those operating largely in normative conformity but engaging in behavior that puts them at risk of being defined as a moral monster (whether from possessing small amounts of marijuana, or engaging in 
drinking above the legal limit but below the individual threshold of drunkenness). Such resistance raises costs of governance, creating a vicious circle in which both punitiveness and dissatisfaction with governance increase together.

The civic culture account focuses on the role of the state in defining and enforcing criminal laws and the consequences for an individual's likelihood of cooperation. Missing from this is the significance of crime and fear of crime as "regulators." One can easily agree that it's preferable to have a thriving culture of civic participation that makes all forms of government more effective than a desiccated one in which citizens crouch behind doors, uncertain whether to fear criminals or the police more. That democratic self-government is difficult to sustain in the latter is also a real fear. Less clear is whether crime-control strategies themselves should be seen as exacerbating such a spiral of civic collapse. For example, crime and fear of crime may independently erode civic participation by causing people to withdraw further and more rapidly from communities that are already experiencing transitional pressures (Skogan 1990). Some have argued that aggressive enforcement of criminal laws, especially minor public-order norms, will have positive effect on civic participation by drawing people back into the public (Wilson and Kelling 1982). The aggressive use of street stop-and-search tactics and enforcement of public-order offenses have been deployed in New York to some recent critical acclaim (Bratton 1996a, 1996b).

In short, from this perspective, it is not always clear whether the priority of crime control in contemporary governance is undermining democratic practice or enhancing it. Crime-prevention strategies often focus directly on the role of participation. The successful movement to intensify the criminal status of drunk drivers has produced a broad set of efforts at valorizing new kinds of responsibility among individuals ("friends don't let friends drive drunk"). More recent advertising efforts are targeted at drinkers themselves to be responsible in using alcohol. Such efforts point to sources of governance other than the state and enhance the importance of the individual as an agent of control over self and others. ${ }^{19}$

\section{Ressentiment}

Political Theorist Wendy Brown (1995) also views the social solidarity based on victim identity as potentially disastrous for a democratic political culture. Brown focuses on the claims of victimization by women and minority groups who have suffered historic and ongoing forms of oppression and domination. She offers an empathetic critique of the dangers of forming political identity around the wounds of oppression. What Brown calls

19. It is difficult to know how important such norms are. 
"politicized" identity is a potent source of mobilizing political participation, but she argues it also carries a high risk of locking people into the very categories generated by their oppression. The satisfaction that comes from avenging oppression carries the price of reinforcing the very categories of the original victimization. It also tends to reconfigure relationships so that law and the state become inevitable intermediaries (Brown 1995, 27).

Brown's critique can be extended beyond the role of victim identity among feminist and critical race activists to the more general cultural milieu of crime. The point is not that sexism and racism can be reduced to the category of crime anymore than to one another, but that they are linked together through the increasingly politicized identity of the victim. In its own way, the crime-centered "victims' rights movement" has in the 1980s and 1990s usurped the place of feminism and antiracism in articulating the kind of governance that victims demand. ${ }^{20}$ Feminism and antiracism, even as they produce the kind of victim identity that Brown addresses, have important self-limiting capacities in this regard. Feminists and antiracists confront the mechanisms of oppression and exploitation on a routine and systematic basis. Crime-victim subjectivity is all too concrete for some, but it has come to function as an all-purpose form of oppression for many whose contact with crime will be mainly through the media. It is perhaps because of this that sociolegal scholars have long observed that those who are the most severely affected victims of sexism and racism (e.g., prostitutes or teenaged black males in the juvenile justice system) qualify least as "genuine" victims of crime.

Brown's analysis helps counterbalance the emphasis on faction implicit in the critique of governing through crime as racism discussed above. No doubt numerous enduring cultural narratives help channel racial animus, especially against African Americans, into demands for security and vengeance against criminals. However, crime victimization is such a powerful basis for identity in contemporary U.S. society partly because it is possible to make it so inclusive. Brown recognizes that the dangers of governing through crime are also those of unification within forms of subjectivity that are themselves too ungrounded in history or politics to generate effective formations of democratic will.

As traditional pluralist competition for state resources comes to focus on crime, groups find strategic reasons to pursue the goods provided by such

20. The relationship between feminist work on rape and sexual harassment, and the more general victims' rights movement, has been very complicated. In some countries-England, for example - the problem of women as victims of sexual crimes was the critical crossover issue for involving government administration in building a victim movement (Rock 1990). In the United States there have been symbiotic links but also important tensions. Feminist groups have used their influence to support reform of rape law and domestic violence enforcement in ways that parallel the larger victims' rights struggle and constitute some of its greatest successes. At the same time crime victims who become involved in victims' rights groups are often women who are not attracted to feminism. 
a government (Simon and Spaulding 1999). Less clear is how governable the multiple fragmented publics constituted by such politics are, and conversely, how much punishment allows real development of the capacities of these new publics. ${ }^{21}$ Identities based on victimization, in Brown's analysis, produce subjects that are increasingly less capable of defining their interests in terms that can be effectively resolved in the boundaries of democratic politics. The astounding political success of recent punitive legislation like 3-strikes and Megan's Law shows that crime is not necessarily a wedge issue. Almost all demographic segments of the population, and both political parties, supported these measures. On the other hand, one may fear that they produce a kind of false unity around narratives whose compelling facts provide potent political mobilization but little mandate to govern.

Governing through crime increasingly includes efforts to govern victims themselves and not just criminals or those suspected of crime. While classical criminal laws placed restrictions on the dangerous in the name of protecting the innocent, sexual offender notification laws like Megan's Law aim at affecting the behavior of the innocent in the name of managing the dangerous. In so doing it redraws the lines of responsibility between family and state. Potential victims are encouraged to take preventive measures in the way they dress, move through the city, and conduct basic economic transactions (Clarke 1995). These measures may in fact be more effective than those directed at potential criminals, since they target obedient citizens and utilize their self-discipline. Indeed, one might think of crime prevention as a way of governing the less controllable (potential criminals) through manipulating the more controllable (porential victims).

Much of this does not conform to either a passive or a submissive role of a victim enthralled by a state. Some crime-prevention techniques skip the subject altogether in favor of governing the environment, but other tactics aim at making the potential victim a manager of their own risks (and those of others). These new technologies of crime prevention create a potentially very different political effect than state-oriented vengeance strategies (Simon 1999c). They are often based in the private sector, encouraged by tort liability, paternalistic concern, and even market forces (Shearing 1996). They emphasize technologies of loss prevention and harm reduction rather than rituals of accusation and punishment (O'Malley 1996). They tend to avoid the identification of specific victims and perpetrators. (Measures can be taken by anyone, and the need to deploy them is typically justified by environment or routine activities than by subjectivity).

21. Political scientists and others have observed a trend toward fragmentation of the public (both politically and culturally) since the 1960s (Inglehart 1977, 1990; Jameson 1991) in liberal postindustrial societies. For the argument that this fragmentation helps directly feed the salience of crime and punishment to electoral politics, see Caplow and Simon 1999. 
As a result of their private-sector locus, crime-prevention governance tends to be very result oriented and thus less susceptible to the rent-seeking behavior of traditional, modern crime-control bureaucracies. For the same reasons, however, these measures carry a great risk of enhancing the problem of exclusion. Private crime-prevention efforts may or may not consider the runoff effects on other communities (opportunistic crime shifted from one neighborhood to another), or care about protecting potential users from the negative externalities ranging from hostile and suspicious treatment at the hands of private police to the mere inconvenience caused by removing public transportation links to a shopping mall.

These technologies require us to look beyond the relationship of citizen to state in understanding the circumstances of democratic governance. We should not assume punitiveness as a culturally fixed desire exogenous to government. Even opinion-survey data suggest that public expectations about punishment are ambiguous. A recent national survey found that only higher education and gun ownership were consistent predictors of punitiveness (with education tending toward less and guns tending toward more punitiveness) (Flanagan and Longmire 1996, 73). Rather than specific political cultures of punitiveness (Stinchcombe 1980), we might think of a far wider and shallower public culture of crime shaped in quite changeable ways. Indeed, these attitudes may express frustration with government itself as much as with crime. The same survey found that a majority favors early release for prisoners who behave well, but rejects having parole boards with discretion to release prisoners (Flanagan and Longmire 1996, 88). Support for lengthy imprisonment and executions expressed frustration and skepticism about government as well as fear of the offender (Ellsworth and Gross 1994, 42).

\section{MEGAN'S LAW}

Any attempt to think through the politics of so broad a field as governing through crime must confront the sheer complexity of the penal state (O'Malley 1999, 175-79). This final section takes a closer look at one of the most politically potent examples of recent penal law making, which opens a window into the way governing through crime is being articulated into a reconfiguration of government. In $1994 \mathrm{New}$ Jersey adopted the first of a wave of sexual offender community-notification laws under the name Megan's Law. The act was actually a host of measures aimed at the state's treatment of convicted sex offenders. ${ }^{22}$ The most widely publicized portion

22. Under the name Megan's Law, the New Jersey legislature actually adopted 10 separate measures against sex offenders including extending terms, making the murder of a child under 14 an aggravating circumstance for purposes of New Jersey's death penalty, and intro- 
required sex offenders in the state to register with state authorities and authorized the state to assess the risk level of sex offenders and provide notification to families and organizations concerned with children who might be at particular risk because of the residential location of the offender.

The law took its name from a seven-year-old girl, Megan Kanka, murdered near her home in Hamilton Township, New Jersey. The man convicted of her murder, Jesse Timmendequas, was twice convicted of sex offenses against young female children, one of which almost resulted in the death of the victim. Megan's murder became a rallying point for victims' rights activists who attacked the state's efforts at policing sex offenders. These groups, prominently featured by the media, framed the issue as one of the betrayal of parents by a state unable to control predators and unwilling to empower citizens to protect themselves. The movement to require registration and notification of sex offenders swept the country in the 1990s following several well-publicized crimes including the Megan Kanka case (Small 1999, 1458). Today every state has a registration law, and nearly 20 have notification of citizens. Some under the name Megan's Law, while others have attached the name of local child victim.

The issue of child sex abuse had been a growing locus of governmental attention and moral panic (Hall et. al. 1979; Cohen 1972) since the 1980s (Jenkins 1998; Logan 2000a, b). The thrust of Megan's Law was nationalized by the United States Congress in the Jacob Wetterling Crimes against Children and Sexually Violent Offender Registration Act, 42 U.S.C. § 14,071 (1994), which required states to maintain registries of convicted sex offenders and release information "necessary to protect the public." These laws reflect a set of somewhat different governance capacities than we associate with the crime-control efforts of the state-for example, the burgeoning prison system, which for all its recent high-tech bells and whistles, at best evidences the continuing ability of state governments (and the federal government) to pour concrete, hire correctional officers, and maintain a larger version of the "carceral archipelago" (Foucault 1977, 298) familiar in the United States since the 1830s. The essential elements of this regime-prisoners, guards, and locked facilities--have existed in easily recognizable form throughout this period. In contrast, the sex offender registration and notification laws model a different picture of governing through crime with quite different elements. Here I want to concentrate on three of them: the constitution of crime victims as the subjects of a democratic polity; the sex offender as a risk to children; and state expertise and power as risk prediction and communication. 


\section{A. The Victim As Sovereign}

Megan's Law is a story about the power of a social movement, the victims' rights movement, to command remarkable attention from state legislatures and Congress. Victims' rights has emerged over the past 25 years as one of the most important social movements of our time, comparable in its influence on our political culture to the civil rights movement or feminism. In part because of the enormous appeal of victimization to television media, the victims' rights movement has been able to make visible a whole host of criminal justice decisions that until recently were made with little attention to public justification. The demand for accountability to victims has put new constraints on courts, parole boards, and governors (Shapiro 1997). ${ }^{23}$ The recently proposed constitutional amendment on victims' rights promises to embed these influences in unpredictable ways into the criminal process and perhaps beyond.

Beyond its legislative success, the victims' movement has been most important in broadening crime victimization from a social problem requiring government action to a status authorizing one to act virtuously as a citizen. Consider, for example, remarks that Attorney General Janet Reno made in a speech to a victims' rights conference:

I draw most of my strength from victims, for they represent America to me: people who will not be put down, people who will not be defeated, people who will rise again and stand again for what is right ... You are my heroes and heroines. You are but little lower than the angels. (Shapiro 1997)

Allowing for the excess that political discourse requires on such occasions, something remaining speaks the truth about victims in contemporary politics. In American history the yeoman farmer and the industrial worker have been among those figures that for a time capture in the broadest possible ways the boundaries of democratic citizenship both in its responsibilities and its needs. In our time the crime victim is emerging as a dominant representation of the governable interests of the population. This is true not only in the relationship of citizen to state but also in the institutional settings of work, family, and education.

This is perhaps the significance of what has been one of the most influential aspects of Megan's Law: its name. Laws named after dead children have become one of the markers of our era replacing earlier traditions of naming laws after legislators (e.g., the Wagner Act or the Volstead Act). Megan's Law demands that we consider Megan's fate. The structure of the

23. Bruce Shapiro relates how Penny White, a member of the Tennessee Supreme Court, was removed from office by a campaign mobilized after she concurred in the reversal of one death sentence (Shapiro 1997). 
law, shaped around the specific experience of Megan's death, marks Megan's own subject position as the law's coordinates (which is not to say that the actual administration of this law will be able to operate in this way). Megan's Law testifies to the importance of the politics of identity in contemporary political life, and to the importance of victimization to the politics of identity (Rajchman 1995). As a consequence of this monumentalizing of Megan, the law brings us before the specificity of Megan Kanka as a young white female killed near her home in a suburban area coded in popular political geography as safe. Indeed, the only murder (other than celebrity ones) that has attracted this kind of attention before a trial has even taken place is that of Polly Klas, a young white girl from a town in northern California previously best known for being the site of President Reagan's famous "morning again in America" commercials during the 1984 presidential campaign. Klas was literally taken out of her home and murdered by a repeat offender (Schrag 1998, 227-28).

If Wendy Brown (1995) is right that the experience of victimization in contemporary society is replacing the recognition of class solidarities, it is not surprising that it is occurring in the victimization of figures like Megan Kanka and Polly Klas, from white middle- and working-class families (themselves increasingly disempowered by the conditions of late-twentieth-century capitalism). ${ }^{24}$ Brown suggests that the tendency of an identity based on victimization is an intensification of the politics of ressentiment, which finds its satisfaction most in punishment.

Politicized identity, premised on exclusion and fueled by the humiliation and suffering imposed by its historically structured impotence in the context of a discourse of sovereign individuals, is as likely to seek its own or collective liberation through empowerment. Indeed, it is more likely to punish and reproach-"punishment is what revenge calls itself; with a hypocritical lie it creates a good conscience for itself"-than to find venues of self affirming action. (Brown 1995, 71, quoting Nietzsche 1954, 242)

In anchoring the law's authority in a deceased child, Megan's Law describes a kind of political community that may incorporate nearly everybody but in an inert and passive form that is anything but self-governing. Ironically, at a time when citizenship is being reinterpreted to demand greater levels of individual responsibility and risk taking, Megan's Law constructs an infantilized political community incapable of formulating interests that are not for protection against others. As Brown (1995) would suggest, in gathering and recognizing people in their vulnerabilities to predatory attack, Megan's Law confines subjects to a narrative with a limited set of objectives, a built

24. Part of the dark genius of David Lynch's television series Twin Peaks was placing a dead young white girl at the center of its mythic late 1980 s exurban community. 
in bias toward the state's own most authoritarian agencies for social control, and the risk of pathological overreaction.

\section{B. Intolerable Risks}

If Megan's law helps make victimization into a constitutive experience for the participation of the people in their own government, it also helps constitute another more select group of people as belonging to the class of monsters (i.e., the aforementioned "sexual predators"). New Jersey and most other states have simply placed all convicted sex offenders into the class of predators, leaving it to administrative decisions to sort them for purposes of the law's notification function. ${ }^{25}$ The legislature of New Jersey made a finding in Megan's law:

The danger of recidivism posed by sex offenders and offenders who commit other predatory acts against children, and the dangers posed by persons who prey on others as a result of mental illness, require a system of registration that will permit law enforcement officials to identify and alert the public when necessary for the public safety. (N.J. Stat. Ann. § 2C:7-1[a][West 1996])

In deploying the terms predatory and prey, Megan's Law invokes nonhuman forms of danger. Over time the law may bequeath us new generations of state-defined "monsters" who can be neither altered or eliminated but only managed. ${ }^{26}$ Those who fall under the technical boundaries of Megan's Law will be defined for the rest of their lives as "sexual predators" (Clawges 1996). The law having defined a problem of governance, sexual predators, an administrative process will set to work employing the technologies of power available to it against this political enemy.

The rationality of government associated with the social democratic governments in the United States and western Europe for the first three decades after World War II was best expressed in the great risk-sharing devices like workers' compensation, the pension systems, and the health care systems (Rose 1999). For much of the twentieth century the central questions of domestic politics had to do with managing this social risk sector. Correctionalism in penology, with its emphasis on community corrections,

25. The legislation adopts as public policy a set of assumptions about sexual offenders that is part of a highly contested field within criminology and psychology.

26. While there is both popular and scientific support for treating "sex offenders" as a special class, the New Jersey version of Megan's Law sweeps broadly in its registration requirement, including all convicted of aggravated sexual assault, sexual assault, aggravated criminal sexual contact, and certain kinds of kidnapping, and those who attempt these crimes if they are found by the state to be "characterized by a pattern of repetitive, compulsive behavior" (see N.J. Stat. Ann. \$§ 2C:7-2[b][1]-[3] [West 1996]). 
was a part of this. Even the risks of criminals must be socialized, channeled back into communities whose security is in that sense tied up with its capacity to normalize (including through the development of a specialized rehabilitative sector).

Governing through crime in the United States has run along with moves to scale back this social sector and introduce more principles of disaggregation into it. A zero-sum game model of risk is replacing the social solidarity of the past. We see this expressed throughout the culture and in the everyday choices of the population. The hard time of prison, from this perspective, is an artificially created hyper-risk zone occupied by those whose removal in large enough numbers from society is promised to lower risks somewhat on the outside. Megan's Law and its progeny produce not simply new entitlements or sanctions but a model of the risk relationship in which the terms could hardly be less solidaristic. Beginning on the already charged ground of child sexual abuse, Megan's Law frames the risk as one of assault by strangers. In this space there are few equities upon which to imagine collective forms of risk reduction. The role of government can only be to reduce the risks of the child, regardless of how marginally, at the expense of the convicted sex offenders, regardless of how severely.

Megan's Law has no therapeutic component. Like the new laws aimed at preventively detaining some of the highest-risk sex offenders, the explicit functions is to exclude, to banish. Long before the great confinement associated with the disciplinary regimes of hospital, prison, and schools, the exclusion of lepers, according to Foucault, operated as a form of government by elimination. There is little doubt that if one were looking for modern lepers, repetitive obsessive sex offenders would be high on one's list. But there is little reason to believe that the model of subject formation represented by Megan's Law will be limited to this particular issue. ${ }^{27}$

\section{Megan's Law as Democratic Penality}

Social liberalism made information a critical vehicle for state intervention into the population. Penology was part of this. The capacity to probe the subjectivity of delinquents and criminals was part and parcel of managing social problems through nuanced interventions in families and communities. The emerging features of advanced liberalism suggest that the state, and agencies like the police, increasingly become dealers in information

27. Representative Jackson-Lee of Texas spoke in support of the federal Megan's Law by invoking another young female murder victim, Monique Miller of Houston, Texas, who, as Ms. Jackson-Lee put it, "was brutally murdered and sexually abused by a repeat offender" (142 Cong. Rec. H62 [Lexis]). The murderer of Polly Klas was also a repeat offender. Whatever core of reality there may be to the legal definition of sexual predator, repeat offenders, especially in the age of widespread imprisonment, must be a heterogeneous lot (Caplow and $\mathrm{Si}$ mon 1999). 
that constitutes its primary intervention (Ericson and Haggerty 1997). One of the most unusual features of Megan's Law is its focus on information. In the legislative campaign for Megan's Law, this information logic was framed in populist terms of ineffective elites and ordinary people forced to grapple with menacing evils. As Maureen Kanka put the matter in a letter written to the House Judiciary Committee:

If pedophiles are going to be out on the street where they can accost children, then parents have the right to know if they live on our streets. My daughter Megan would be alive today if I had known that my neighbor was a twice convicted pedophile. I had responsibility to protect my daughter. I have always told my children that I would never let anything happen to them. But I guess I lied. I could not protect my Megan as she was being brutally raped and murdered across the street from my home. I have to live with the fact that she screamed out my name as she was being murdered. (Testimony to the House of Representatives, Judiciary Committee, 1996 WL 117175 [1996 Federal Document Clearing House]; emphasis added)

Although Maureen Kanka may or may not have had it consciously in mind, her testimony provides a critique of the technologies of power associated with the social liberal state and its penality. The traditional answer of state penology to the problem posed by Megan's Law was the creation of parole agents (Simon 1993; Lynch 1998), a hybrid of factory supervisor, therapist, and prison guard who were expected to "supervise" released offenders like Jesse Timmendequas. Had Timmendequas been on parole (he had completed his term of supervision), it is doubtful that a parole agent would have permitted him to live with another sex offender. The agent would also likely have visited with parents of vulnerable-age children in the vicinity. Ironically, the current preference for imprisonment as the penal sanction of choice has left parole little more than a lower-cost prosecutorial function in many states (Simon 1993). In this sense, Megan's Law reflects a model for governance that is becoming a familiar pattern in the advanced liberal state: the centrality of risk to the construction of governable problems; the delegation of responsibility for risk reduction to private and nonspecialized actors often with little political influence; the state little more than a provider of information (Rose 1999).

Risk prediction has become widespread in the criminal justice system (Feeley and Simon 1994). These mechanisms, fitted to the other needs of administrative bureaucracies, now influence decision making at virtually every point in the process from being stopped or interrogated by the police, to bail decisions, to jail and prison custody decisions, to conditions of release. Under Megan's Law the threat of private action is added to this system but remains, in fact, tied to the official control of the risk-evaluation 
process (Logan 2000). What is interesting about Megan's Law is the degree to which risk assessment has separated itself from other substantive tasks of criminal justice-incapacitating, rehabilitating, and so on-and become an autonomous governmental practice intended to have its own direct effects.

Megan's Law recognizes victims as subjects, but it also brings victims into its object field as targets of power. Megan's Law is a way of governing people through the experience of victimization. Sex offenders are required to submit to certain kinds of reporting, and the guardians of children are promised information on proximate high-risk offenders, but in between, Megan's Law governs through other relations-parents to children, parents to schools and youth centers, all of the above to the police. Megan's Law also affirms community groups involved with religion, schools, and youth generally as elements of a crime-control strategy against sexual abuse. Most institutions involved with children have for some time been under special legal obligations to report signs of child abuse to the state. Megan's Law may be the first statute to make these institutions part of the specific response to offenders (as opposed to victims). It makes these groups part of the state's power to surveil and potentially to punish (although violent actions against the person are not authorized). It does not purport to prescribe all these relationships, but it sets them into motion with its circulation of knowledge. Thus, the experience of victimization, which begins as a kind of denunciation of the liberal state and its failings, becomes a mandate to a set of nonstate actors to take part in governing the potential relationship between sex offenders and children.

Along with the victim and the perpetrator, and significantly implied in the valorization of both, is a complicated and contradictory message about state power. The political rhetoric behind Megan's Law has consistently invoked the theme of state failure. Existing laws and the administrative bureaucracies do not adequately protect children from sex offenders because of plea bargaining, deceptive sentencing laws that allow prisoners to earn early release regardless of their treatment, and inadequate post-release preventive supervision. From this perspective, state efforts at crime control actually render citizens more vulnerable by hiding the need for self-defense and creating administrative bodies jealous of their knowledge advantages over the public that pays their salaries. But Megan's Law also redefined the role of state actors in a way that insulates government from failure. If the primary job of government is collecting and dispensing information about sex offenders, and if it is primarily a problem of family and community to effectively use that information to protect children, than the state is vulnerable to certain kinds of mistakes (e.g., failing to classify a particular offender as worthy of notification) but insulated from the ultimate failures of abused and murdered children. 
This model can be criticized on a number of grounds. Most especially, it presumes a family that has the resources to protect itself by choosing a location in which the streets are safe and a family structure that allows for the kind of surveillance that Maureen may have been able to provide Megan had she been alerted to that particular threat. The specific slogan of Megan's Law has been "empowering families, women, and children." Its congressional supporters made vague references to how the Megans and Maureen Kankas of this world can seek their own protection "to take the necessary precautions to ensure that there are not second, third or fourth victims" (142 Cong Rec. H4451, 55 [Lexis]). These supporters said much less about what those precautions might be. Others, those whose employment and housing situations make children unprotectable through a strategy of commands to stay away from certain persons, enforced by personal observation, are strangely out of place in the law. Indeed, their plight can now only look more like a kind of irresponsibility on their part. Once the knowledge is provided, those parents who do not act to protect their children personally will have to answer for their dependence on the state.

In promising a direct circuit to state knowledge about offenders in the community Megan's Law repudiates the discretionary, expertise-based control system associated with the social liberal state and its penality. It remains to be seen, of course, what kinds of real circuits of knowledge/power these laws create. The rhetoric of the law invokes the idea of meaningful communities acting in self-defense. In most states, however, the law vests in judges, prosecutors, or a state commission to assess risk and determine at what risk level notification should take place. The parole officer is replaced by the risk-assessment consultant, but the power over the knowledge remains centralized. Indeed, in Florida and California, for example, the state has created a virtual community over the Internet by allowing citizens to search for sex offenders regardless of their own proximity or danger. Also, by defining the large and diverse population of convicted sex offenders as belonging to a unitary class of "sexual predators," these laws actually increase the experience of threat in the community (Small 1999, 1456). To the extent that community really means "local knowledge," these circuits seem likely to intensify mistrust of one's neighbors while building new kinds of dependency on the state.

\section{CONCLUSION}

Governing through crime is probably a feature of most societies at most times. During the past quarter century, however, the United States has experienced phenomenal growth in the importance of governing through crime. Because the incarcerated population, despite its unprecedented growth, is still small relative to other sites of governance like schools, 
businesses, and families, it is tempting to view it as a specialized sector. It is easy to show that incorporation into this sector is most unequally spread among all the most problematic differences in societies. But governing through crime seems to have a broader purchase in a number of ways that are harder to measure than the formal jurisdictional demography of the criminal justice system.

Elsewhere I have offered a richer descriptive account of governing through crime and sought to canvass explanations for why it seems to be undergoing explosive growth (Simon 1997). In this article I have concentrated on what seems one of the most disturbing and paradoxical features of this trend toward governing through crime-its relationship with democracy. Governing through crime has long roots in democratic practice and theory. As James Q. Wilson (1996) has recently reminded us, imprisonment is an almost inevitable response to crime in democracies, which can neither ignore popular discomforts nor brutally "disappear" the enemies of order. One can, in fact, make a strong case within the discourses of mainstream political theory that the criminal law is among the most democratic form, of exercising power, at least when one is focusing on that part of governance characterized as the state. ${ }^{28}$ Clearly the current ascendance of governing through crime is supported by substantial majorities participating in electoral politics. ${ }^{29}$ But recognizing the profound links between democracy and governing through crime cannot make us sanguine to the growing role of the former. The expansion of governing through crime poses a danger to democratic practices and institutions. These dangers exist regardless of whether the reasons for incarcerating people are sound and the procedures used utterly fair (neither of which can be taken as assumptions in this country).

It is essential to appraising the real stakes in these broad changes in American political and legal culture that they have corresponded to a broad reconfiguration of the rationality of governance in liberal societies. After a century in which the freedom of the liberal subject was secured by socializing risk through large structures of solidarity, and in which the state sought to govern through expert knowledge of population and its social conditions, a fundamental transformation of liberal rule is underway. The reasons why crime has become such a central surface for this transformation are beyond the scope of this article, which identified the consequences of shaping the new terms of risk spreading and management in the context of crime. While fear of crime has eroded the political structures of social liberalism (large cities, public schools, social welfare), the salience of crime is establishing

28. That would seem to be the logic of the libertarian position that has recently been so influential in law and politics.

29. One can show how much this support is based on distorted information (see, e.g., Donziger 1996), but this essay argues that it is a mistake to ignore the genealogies that anchor crime in popular thought. 
new relations in terms likely to exacerbate racism, promote inequality, and preserve some of the least defensible features of the old regime (patronage government driven by large public unions and election contributions).

Robert Post (1995) has argued that American democracy has historically been a balancing act between tendencies toward communitarian solidarities and engines of managerial power. Post argues that the great challenge of American constitutional law is sustaining a functioning democratic state dependent on both community and bureaucracy, while being colonized by neither. Democracy requires a space of individual choice that is suffocated when community values are rigidly enforced as law. On the other hand, democracies require citizens with values and interests that can only come from the normative creativity of community (Post 1995, 189). Where protecting individual liberty means negating community values, the very source of democratic citizenship may be suffocated. Likewise, democracy is both dependent upon and endangered by managerial practices that make it possible to carry out the democratic will and distort its formation. Where government does not have the organizational strength to carry out the mandates of law, democratic choice ceases to have much meaning (Cover 1986). Yet large and powerful enforcement organizations pose their own threat to democracy, both by the great concentration of human and other capital that can have an undue influence, and by the often stifling pressure of managerial considerations.

Governing through crime threatens to exacerbate this historic tension. First, as communities become more and more defined by the experience of personal victimization - whether real or imagined, firsthand or mediated by television-the criminal law emerges as a tempting way to reaffirm the very existence of community (Kennedy forthcoming). We are fast becoming a society in which we must compete in virtually every aspect of life, while simultaneously reinforcing a public ideology that brooks no real recognition of conflicts other than those inspired by perversity and criminality. Crime control reproduces the community as a series of links running between the state and various intermediate organizations (schools, churches, families). Meanwhile, what we might take as the sociological reality of community (i.e., the realm of more spontaneous interactions structured by shared space and custom) is actually made to appear more dangerous and less worthy of trusting engagement. Megan's Law is touted as community empowerment, but it replaces reliance on the "local knowledge" of neighbors with new forms of dependence on the state. In short, it places management where the gesture of community points.

While the priority of governing through crime control reflects an increasingly desperate attempt to shore up community, the actual expansion of the criminal law goes along with a massive expansion in the managerial functions of government. A larger and larger proportion of the population 
finds that they are being directly managed by the criminal justice system. An even larger proportion is exposed to this managerial force through policing and community supervision. But while this managerial power may effectively represent majority political support, it also stifles the kinds of interactions and potential solidarities that might form new directives for both social order and governing.

\section{REFERENCES}

Anderson, Elijah. 1998. The Social Ecology of Youth Violence. In Youth Violence: Crime $\mathscr{E}$ Justice, ed. Mark H. Moore and Michael Tonry. Vol. 24. Chicago: University of Chicago Press.

Balkin, J. M. 1998. Cultural Software: A Theory of Ideology. New Haven, Conn.: Yale University Press

Barry, Andrew, Thomas Osborne, and Nikolas Rose, eds. 1996. Foucault and Political Reason: Liberalism, Neo-liberalism, and Rationalities of Government. Chicago: University of Chicago Press

Baudrillard, Jean. 1983. In the Shadow of the Silent Majorities or "The Death of the Social." New York: Semiotext(e).

Beck, Ulrich. 1992. Risk Society: Towards a New Modemity, trans. Mark Ritter. London: Sage.

Becker, Gary. 1968. Crime and Punishment: An Economic Approach. Joumal of Political Economy 76:68-95.

Beckett, Katherine. 1997. Making Crime Pay: Law \& Order in Contemporary American Politics. New York: Oxford University Press.

Beckett, Katherine, and Bruce Western. 1999. How Unregulared Is the U.S. Labor Market? The Dynamics of Jobs and Jails. American Joumal of Sociology 104:1030-60.

- Forthcoming. Social Control, Welfare, and the Transformation of the State. American Sociological Review.

Berk, Sarah Fenstermaker, and Donileen R. Loseke. 1981. "Handling" Family Violence: Situational Determinants of Police Arrest in Domestic Disturbances. Law and Society Review 15:317-346.

Blumberg, Abraham. 1967. The Practice of Law as a Confidence Game. Law and Society Review 1:15-39.

Bonczar, Thomas P., and Allen J. Beck. 1997. Lifetime Likelihood of Going to State or Federal Prison. Washington, D.C.: U.S. Department of Justice.

Bratton, William J. 1996a. New Strategies for Combating Crime in New York City. Fordham Urban Law Journal 23:781-795.

- 1996b. How to Win the War Against Crime. New York Times, 5 April 1996, A27.

Brown, Wendy. 1995. States of Freedom: Power and Freedom in Late Modernity. Princeton, N.J.: Princeton University Press.

Caplow, Theodore, and Jonathan Simon. 1999. Understanding Prison Policy and Population Trends. Prisons: Crime and Justice: A Review of Research, ed. Michael Tonry and Joan Petersilia, 63-120. Vol. 26. Chicago: University of Chicago Press.

Christie, Nils. 1993. Crime Control as Industry. London: Routledge.

Clarke, Ronald V. 1995. Situational Crime Prevention. In Building a Safer Society: Crime and Justice, ed. Michael Tonry and David Farrington. Vol. 19. Chicago: University of Chicago Press. 
Clawges, Timothy L. 1996 Political Posturing or Real Change: Analysis of the Legislature's Special Session on Crime. Pennsylvania Lawyer, March/April 1996, 20.

Cohen, Stanley. 1972. Folk Devils and Moral Panics. Oxford: Blackwell.

Cole, David. 1999. No Equal Justice. New York: New Press.

Coombs, Mary I. 1987. Shared Privacy and the Fourth Amendment, or the Rights of Relationships. California Law Review 75:1593-1664.

Cover, Robert. 1986. Violence and the Word. Yale Law Journal 95:1601-1629.

Cruikshank, Barbara. 1994. The Will to Empower: Technologies of Citizenship and the War on Poverty. Socialist Review 23:29-55.

Currie, Elliott. 1998. Crime and Punishment in America. New York: Metropolitan Books.

Davis, Mike. 1990. City of Quartz: Excavating the Future in Los Angeles. London: Verso. 1998. Ecology of Fear: Los Angeles and the Imagination of Disaster. New York: Metropolitan Books.

Dean, Mitchell. 1991. The Constitution of Poverty: Towards a Genealogy of Liberal Governance. London: Routledge.

Deavere-Smith, Anna. 1993. Fires in the Mirror. New York: Anchor Books.

Dionne, E. J. Jr. 1991. Why Americans Hate Politics. New York: Simon and Schuster.

Donziger, Steven R, ed. 1996. The Real War on Crime: The Report of the National Criminal Justice Commission. New York: HarperPerennial.

Dubber, Markus Dirk. 1998. The Right to Be Punished: Autonomy and Its Demise in Modern Penal Thought. Law and History Review 16:113-46.

Dumm, Thomas. 1987. Democracy and Punishment: Disciplinary Origins of the United States. Madison: University of $\mathrm{W}$ isconsin Press.

- 1994. United States. Ithaca, N.Y.: Cornell University Press.

Ellsworth, Phoebe C., and Samuel R. Gross. 1994. Hardening of Attitudes: Americans' Views on the Death Penalty. Journal of Social Issues 20:19-52.

Ericson, Richard V., and Kevin D. Haggerty. 1997. Policing the Risk Society. Toronto, Ont.: University of Toronto Press.

Ewald, Francois. 1986. L'Etat Providence. Paris: Grasset.

1991. Insurance and Risk. In The Foucault Effect, ed. G. Burchell C. Gordon, and P. Miller. Chicago: University of Chicago Press.

Feeley, Malcolm, and Edward Rubin. 1997. Judicial Policy Making in the Modern State: How the Courts Reformed America's Prisons. New York: Cambridge University Press.

Feeley, Malcolm, and Jonathan Simon. 1992. The New Penology: Notes on the Emerging Strategy of Corrections and Its Implications. Criminology 30: 449-74.

- 1994. Actuarial Justice: The Emerging New Criminal Law. In The Futures of Criminology, ed. David Nelken. London: Sage.

Felner, Jamie, and Marc Mauer. 1998. Losing the Vote: The Impact of Disenfranchisement Laws in the United States, 7-8 October. Washington D.C.: The Sentencing Project and Human Rights Watch.

Flanagan, Timothy J., and Dennis R. Longmire, eds. 1996. Americans View Crime and Justice: A National Opinion Survey. London: Sage.

Foner, Eric. 1988. Reconstruction, 1863-1877. New York: Harper and Row.

Foucault, Michel. 1977. Discipline and Punish: The Birth of the Prison, trans. Alan Sheridan. New York: Pantheon.

1991. Governmentality. In The Foucault Effect: Studies in Governmentality, ed. Graham Burchell, Colin Gordon, and Peter Miller. Chicago: University of Chicago Press.

Garland, David. 1985. Punishment and Welfare. Brookfield, Vt.: Gower.

1996. The Limits of the Sovereign State: Strategies of Crime Control in Contemporary Society. British Journal of Criminology 36:445-71. 
1997. "Governmentality" and the Problem of Crime: Foucault, Criminology, Sociology. Theoretical Criminology 1:173-213.

2000. The Culture of High Crime Societies: The Social Preconditions of the New Politics of Crime Control. British Joumal of Criminology 40:347-375.

Garth, Bryant, and Joyce Sterling. 1998. From Legal Realism to Law and Society: Reshaping Law for the Last Stages of the Social Activist State. Law and Society Review 32:409-772.

Gilroy, Paul. 1987. "There Ain't No Black in the Union Jack": The Cultural Politics of Race and Nation. Chicago: University of Chicago Press.

Goodman, Elga A. 1996. Comment: Megan's Law: The New Jersey Supreme Court Navigates Uncharted Waters. Seton Hall Law Review 26:764-802.

Gordon, Diana R. 1994. The Return of the Dangerous Classes: Drug Prohibition and Policy Politics. New York: Norton.

Gusfield, J. 1981. The Culture of Public Problems: Drinking-Driving and the Symbolic Order. Chicago: University of Chicago Press.

Hagan, John, and Ruth D. Peterson. 1995. Criminal Inequality in America: Patterns and Consequences. In Crime and Inequality, ed. John Hagan and Ruth D. Peterson, 14-36. Stanford, Calif.: Stanford University Press.

Hall, Stuart, Chas Critcher, Tony Jefferson, John Clarke, and Brian Roberts. 1979. Policing the Crisis: Mugging, the State, and Law and Order. London: MacMillan.

Hay, Douglas. 1975. Property, Authority, and the Criminal Law. In Albion's Fatal Tree: Crime and Society in 18th-Century England, ed. Hay et. al. New York: Pantheon.

Ignatieff, Michael. 1978. A Just Measure of Pain: The Penitentiary in the Industrial Revolution, 1750-1850. London: Penguin Books.

Inglehart, Ronald. 1977. The Silent Revolution: Changing Values and Political Styles Among Western Publics. Princeton, N.J.: Princeton University Press.

- 1990. Culture Shift in Advanced Industrial Society. Princeton, N.J.: Princeton University Press.

Irwin, John. 1985. The Jail: Managing the Underclass in American Society. Berkeley and Los Angeles: University of California Press.

Irwin, John, and James Austin. 1997. It's About Time: America's Imprisonment Binge. Belmont, Calif.: Wadsworth.

Jameson, Frederic. 1991. Postmodernism, or The Cultural Logic of Late Capitalism. Durham, N.C.: Duke University Press.

Jefferson, Thomas. 1801. Letter of Thomas Jefferson to Elijah Boardman, 3 July 3. Jefferson Papers, Library of Congress, vol. 115, folio 19761.

Jenkins, Philip. 1998. Moral Panic: Changing Concepts of the Child Molester in Modern America. New Haven, Conn.: Yale University Press.

Jordan, Bill, and Jon Arnold. 1995. Democracy and Criminal Justice. Critical Social Policy 44/45 (Autumn):170-82.

Kalven, Harry. 1965. The Negro and the 1st Amendment. Chicago: Phoenix Books.

Kaminer, Wendy. 1995. It's All the Rage: Crime and Culture. Chicago: Addison-Wesley.

Kaplan, John, Robert Weisberg, and Guyora Binder. 2000. Criminal Law: Cases and Materials. 4th ed. Boston: Little Brown.

Katz, Jack. 1988. Seductions of Crime: Moral and Sensual Attractions of Doing Evil. New York: Basic Books.

Kennedy, Joseph. Forthcoming. The Search for Solidarity Through Modern Punishment. Hastings Law Review.

Kennedy, Randall. 1997. Race, Crime, and the Law. New York: Pantheon.

Lichtenstein, Alex. 1996. Chain Gang Blues. Dissent, Fall, 7-10. 
Linebaugh, Peter. 1992. The London Hanged: Crime and Civil Society in the 18th Century. New York: Cambridge University Press.

Logan, Wayne. 2000a. A Study in "Actuarial Justice": Sex Offender Classification. Practice and Procedure 3:593-637.

- 2000b.Liberty Interests in the Preventive State: Procedural Due Process and Sex Offender Community Notification Laws. Journal of Criminal Law and Criminology 89:1167-232.

Lynch, Mona. 1998. Waste Managers? The New Penology, Crime Fighting, and Parole Agent Identity. Law and Society Review 32:839-70.

Madriz, Esther. 1997. Nothing Bad Happens to Good Girls: Fear of Crime in Women's Lives. Berkeley and Los Angeles: University of California Press.

Maguire, Kathleen, and Ann L. Pastore. 1998. Sourcebook of Criminal Justice Statistics 1997. Washington, D.C.: Bureau of Justice Statistics.

Mahoney, Martha R. 1991. Legal Images of Battered Women: Redefining the Issue of Separation. Michigan Law Review 90:1-94.

Meares, Tracey. 1998. Race and Place. Chicago Kent Law Review 73:669-724.

Miller, Jerome. 1996. Search and Destroy: African-American Males in the Criminal Justice System. Cambridge, U.K.: Cambridge University Press.

Nietzsche, Friedrich. 1954. Thus Spake Zarathustra. In The Portable Nietzsche, ed. Walter Kaufman. New York: Knopf.

- 1994. On the Genealogy of Morals, trans. Carol Diethe. Cambridge: Cambridge University Press.

O'Malley, Pat. 1996. Consuming Risks: Harm Minimization, Risk Management, and the Government of "Drug Users." Paper presented to the International Conference on New Forms of Government, University of Toronto, October 1996 (copy on file with author).

- 1999. Volatile and Contradictory Punishment. Theoretical Criminology. 3:175-96.

Parenti, Christian. 1998. Lockdown America: Police and Prisons in the Age of Crisis. London: Verso.

Post, Robert. 1995. Community, Management, and Democracy. Cambridge: Harvard University Press.

Posner, Richard. 1985. An Economic Theory of the Criminal Law. Columbia Law Review 85:1193-1257.

Procaci, Giovana. 1998. Poor Citizens: Social Citizenship and the Crisis of the Welfare States. In Displacement of Social Policy, ed. S. Hanninen. Jyvaskyla, Finland: University of Jyvaskyla.

Putnam, Robert D. 1993. Making Democracy Work. Princeton, N.J.: Princeton University Press.

Radzinowicz, Sir Leon. 1991. Penal Regressions. Cambridge Law Journal 50:422-44.

Rajchman, John, ed. 1995. The Identity Question. New York: Routledge.

Rock, Paul. 1990. Helping Victims of Crime: The Home Office and the Rise of Victim Support in England and Wales. New York: Oxford University Press.

Rose, Nikolas. 1996. Governing "Advanced" Liberal Democracies. In Barry, Osborne, and Rose 1996, 37-64.

. 1999. The Powers of Freedom. Cambridge, U.K: Cambridge University Press.

Rose, Nikolas, and Peter Miller. 1992. Political Power Beyond the State: Problematics of Government. British Journal of Sociology 43:172-205.

Rothman, David J. 1971. The Discovery of the Asylum: Social Order and Disorder in the New Republic. Toronto: Little Brown. 
1980. Conscience and Convenience: The Asylum and Its Alternatives in Progressive America. Boston: Little, Brown.

Salvatore, Ricardo D., and Carlos Aguirre. 1996. The Birth of the Penitentiary in Latin America: Toward an Interpretive Social History of Prisons. In The Birth of the Penitentiary in Latin America: Essays on Criminology, Prison Reform, and Social Control, 1830-1940, ed. Ricardo D. Salvatore and Carlos Aguirre, 1-43. Austin: University of Texas Press.

Sampson, Robert J., and William Julius Wilson. 1995. Toward a Theory of Race, Crime, and Urban Inequality. In Crime and Inequality, ed. John Hagan and Ruth D. Peterson. Stanford, Calif.: Stanford University Press.

Scheingold, Stuart. 1991. The Politics of Street Crime: Criminal Process and Cultural Obsession. Philadelphia: Temple University Press.

Schiraldi, Vincent. 1994. The Undue Influence of California's Prison Guard's Union: Califormia's Correctional-Industrial Complex. San Francisco: Center on Juvenile and Criminal Justice.

Schlosser, Eric. 1998. The Prison-Industrial Complex. Atlantic Monthly, December, 51-77.

Schrag, Peter. 1998. Paradise Lost: California's Experience, America's Future. New York: New Press.

Shapiro, Bruce. 1997. Victims and Vengeance: Why the Victims' Rights Amendment Is a Bad idea. The Nation, 10 February, p. 13.

Shearing, Clifford. 1996. Public and Private Policing. In Themes in Contemporary Policing, ed. William Saulsbury, Joy Mott, and Time Newburn. Plymouth, U.K.: Latimer Trend \& Co., Ltd.

Silberman, Mathew. 1995. A World of Violence: Corrections in America. Belmont, Calif.: Wadsworth.

Simon, Jonathan. 1993. Poor Discipline: Parole and the Social Control of the Urban Underclass, 1890-1990. Chicago: University of Chicago Press.

-1997. Governing through Crime, in Lawrence Friedman and George Fisher, eds.

The Crime Conundrum: Essays on Criminal Justice. Boulder: Westview.

. 1999a. From a Tight Place: Crime, Punishment, and American Liberalism. Yale Law and Policy Review 17: 853-76.

. 1999b. Law after Society. Law and Social Inquiry 24:143-94.

- 1999c. On Their Own: Delinquency without Society. University of Kansas Law Review 47:1001-19.

- 2000. From the Big.House to the Warehouse: Rethinking Prisons and State Government in the 20th Century. Punishment and Society 3:213-33.

Simon, Jonathan, and Christina Spaulding. 1999. Tokens of Our Esteem: Aggravating Factors in the Era of Deregulated Death Penalties. In The Killing State: Capital Punishment in Law, Politics, and Culture, ed. Austin Sarat, 81-114. New York: Oxford University Press.

Skogan, Wesley G. 1990. Disorder and Decline: Crime and the Spiral of Decay in American Neighborhoods. New York: Free Press.

Small, Jane A. 1999. Who Are the People in Your Neighborhood? Due Process, Public Protection, and Sex Offender Notification Laws. New York University Law Review 74:1451-93.

Stern, Vivian. 1998. A Sin Against the Future: Imprisonment in the World. Boston: Northeastern University.

Stinchcombe, Arthur. 1980. Crime and Punishment: Changing Attitudes in America. San Francisco: Josey-Bass. 


\section{LAW AND SOCIAL INQUIRY}

Tonry, Michael. 1995. Malign Neglect-Race, Crime, and Punishment in America. New York: Oxford University Press.

Thompson, E. P. 1975. Whigs and Hunters: The Origin of the Black Act. New York: Pantheon.

Tyler, Tom. 1997. Social Justice in a Diverse Society. Boulder, Colo.: Westview.

Wacquant, Loïc. 1999. Les Prisons de la Misere. Paris. Raison D'Agir Editions. . Forthcoming. The Prison as Ghetto. Punishment and Society.

Wattenburg, Ben J. 1986. Values Matter Most: How Republicans or Democrats or a Third Party Can Win and Renew the American Way of Life. New York: Free Press.

Wiebe, Robert H. 1985. The Opening of American Society. New York: Vintage Books.

Wilson. James Q. 1983. Thinking About Crime. 2d. ed. New York: Basic Books. 1996. Interview with James Q. Wilson. Criminal Justice Matters 25:1-3.

Wilson, James Q., and George C. Kelling. 1982. Broken Windows: The Police and Neighborhood Safety. Atlantic Monthly, March, p. 29.

Wilson, William J. 1996. When Work Disappears: The World of the New Urban Poor. New York: Knopf.

Woodward, C. Vann. 1966. Reunion and Reaction, the Compromise of 1877, and the End of Reconstruction. Boston: Little Brown.

Young, Jock. 1999. Cannibalism and Bulemia Punishment and Society 3:387-408.

Zimring, Franklin, and Gordon Hawkins. 1995. Incapacitation: Penal Confinement and the Restraint of Crime. New York: Oxford University Press. 